\title{
Use of THAM and Sodium Bicarbonate in Correcting Acidosis in Asphyxiated Newborns
}

\author{
D. BERG, M. MÚLLING, and E. SALING \\ From the Department of Obstetrics and Gynaecology, Berlin-Neuköln, and the Department of Veterinary Obstetrics \\ Berlin-Düppel, Germany
}

Treatment of asphyxia of the newborn requires correction of the attendant acidosis, in addition to any necessary artificial ventilation. Currently, two buffer substances are used for this purpose, sodium bicarbonate and THAM (tris-hydroxymethylaminomethane). The effect of these buffers on the respiration of rabbits is the subject of this paper.

\section{Material and Methods}

Further details of material and methods are published elsewhere (Berg et al., 1968).

12 rabbits weighing $2400 \mathrm{~g}$. were anaesthetized with chloral hydrate. Polyvinyl catheters were placed in the femoral vein and artery of one leg. The arterial blood passed through the electrode described below, allowing arterial $p \mathrm{H}$ to be measured continuously. Tracheostomy was performed and a tube inserted into the trachea. Assessment of tidal volume was carried out in a closed system using a small Krogh spirometer, movements of the lid being converted into electrical impulses and registered graphically.

Fig. 1 shows schematically the $p \mathrm{H}$-electrede assembly. Samples of artcrial blocd were equilibrated at short intervals with an $\mathrm{O}_{2}-\mathrm{CO}_{2}$ gas mixture with a $\mathrm{CO}_{2}$ tension of $40 \mathrm{~mm} . \mathrm{Hg}$, and the $p \mathrm{H}$ was measured to give the ' $p H$ (qu 40) value' (Saling, 1966). Knowing the $\mathrm{Hb}$ concentration, the other parameters of the acidbase status, including the actual $\mathrm{PCO}_{2}$, could be extrapolated from the nomogram of Siggaard Andersen (1962).

\section{Results}

Results are set out in Tables I and II. Further details are published elsewhere (Berg et al., 1968).

The influence of THAM administration on respiration and $p \mathrm{H}$ was studied in seven experiments. $0.5-1 \cdot 0 \mathrm{mmole} / \mathrm{kg}$. was injected in $15-25 \mathrm{sec}$.

After about 20 sec., a significant decrease of $\mathrm{PCO}_{2}$ occurred $(\mathrm{p}<0.01)$ amounting to about $20 \mathrm{~mm} . \mathrm{Hg}$, i.e. to about half its initial value. At the same time, ventilation decreased significantly by an average of $78 \%(p<0.0025)$. The respiratory rate fell only slightly, provided that apnoea

Received October 14, 1968 was absent. The decrease of ventilation was thus caused mainly by a fall in tidal volume. On 4 occasions apnoea lasted between 5 and 60 seconds. Respiratory depression lasted between 30 and 120 seconds. Initially, $p \mathrm{H}$ increased by an average of 0.43 ; subsequent to the depression of ventilation, $p \mathrm{H}$ fell almost invariably, due to the increased $\mathrm{PCO}_{2}$, caused by respiratory depression.

Fig. 2 shows a simultaneous record of $p H$ and respiration and illustrates a typical experiment.

In seven experiments the influence of sodium bicarbonate on respiration was studied. 1-2 mmole/ kg. was given within 15-20 seconds. After about 15 seconds, hyperventilation began and continued for more than 3 minutes. The minute volume increased by more than $100 \%$. This increase was statistically significant $(p<0.0025)$. The actual $p \mathrm{H}$ values increased by an average of $0 \cdot 18$, and $\mathrm{PCO}_{2}$ by about $23 \mathrm{~mm} . \mathrm{Hg}$ (or $62 \%$ ) (p < $0 \cdot 0125)$.

Fig. 3 shows a simultaneous record of $p \mathrm{H}$ and respiration in a typical experiment.

\section{Discussion}

These studies were made on adult rabbits. How far are the results of such animal experiments transferable to man, and especially to human newborns? There is little to suggest they are

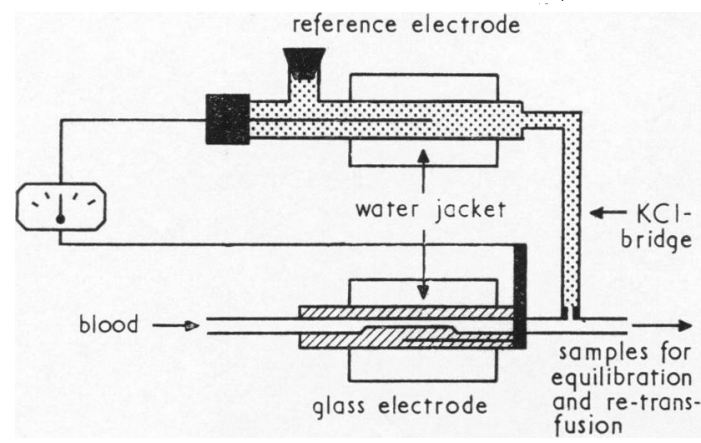

FIG. 1.-Capillary electrode for continuous measurement of $\mathrm{p} H$. 

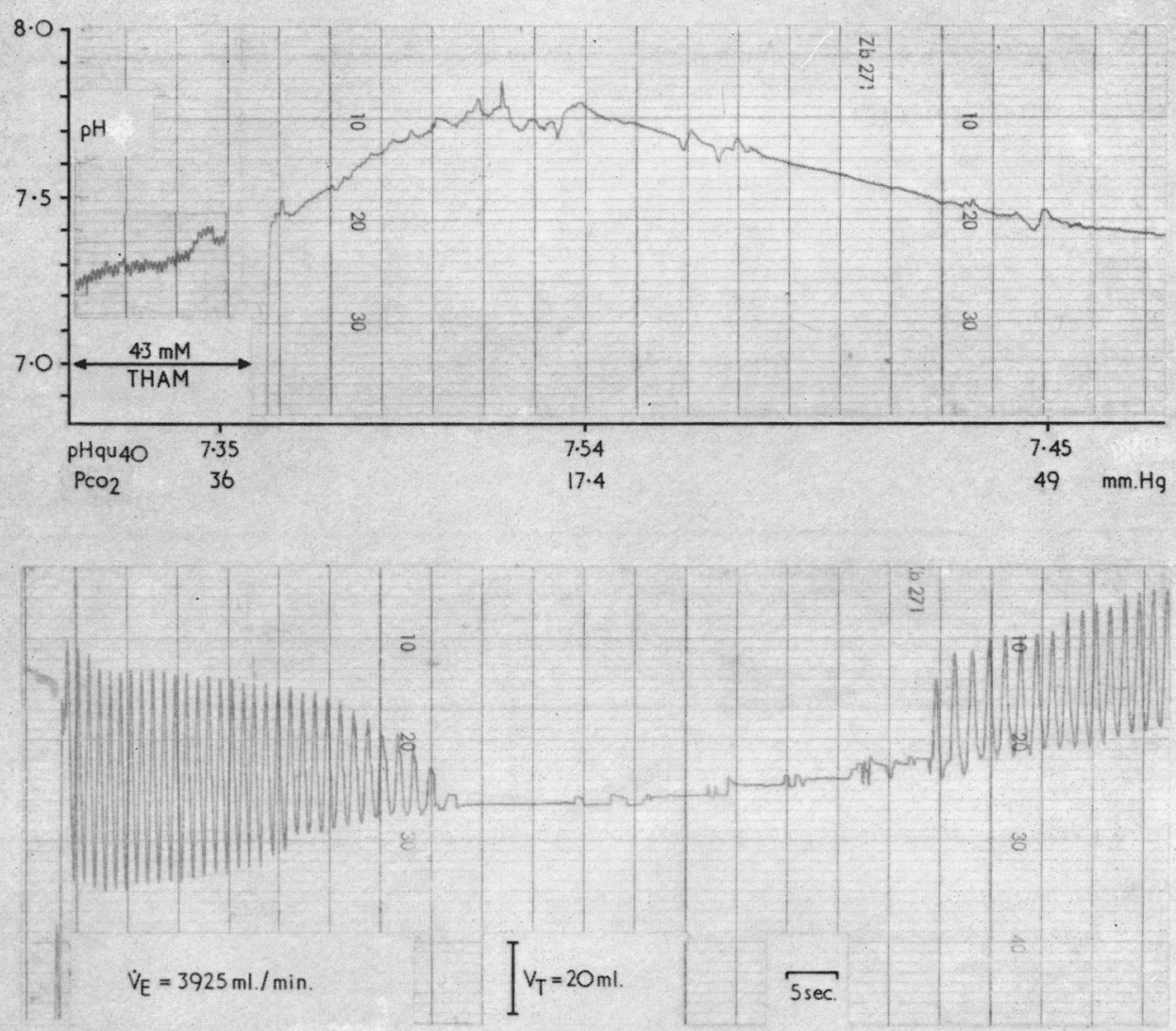

FIG. 2.-Spirogram (lower trace) and arterial $\mathrm{pH}$ (upper trace) before, during, and after injection of 4.3 mmole THAM. Note apnoeic phase. Values for $\mathrm{pH} q u 40$ (see 'Methods') and arterial $\mathrm{PCO}_{2}$ are shown. $\dot{V}_{E}$ : minute volume of respiration in ml./min. BTPS. (The $\mathrm{pH}$ swing recorded at the end of injection was an artefact.) The low pre-treatment $\mathrm{pH}$ in this case was caused by a lactic acid acidosis; this case is therefore not included in Table $I$.

not, having regard to the fact that the chemical regulation of respiration and buffering of blood are fundamental processes which take place qualitatively in the same way in mammalia. It must also be pointed out that the rabbits at the start of an experiment had a near normal $p \mathrm{H}$, which after alkali treatment rose to levels as high as $7 \cdot 65-8 \cdot 0$. Are the physiological effects the same under these conditions as in cases of asphyxia where the $p H$ is raised from a very low value to normal ? Studies published elsewhere (Berg et al., 1968) have shown that there is no qualitative difference between these two situations (see also Fig. 2).

An important side-effect of THAM is the depression of respiration, due mainly to reduction in tidal volume rather than in frequency (Brown et al., 1959, 1961; Jarre, Ketterle, and Reinwein,
1965; Müller-Plathe, 1965; Ngai et al., 1961; Nahas and Lumpkin, 1959; Nahas et al., 1963; O'Connor et al., 1959). Theoretically, the respiratory depression might be caused by one of the following mechanisms.

(1) A pharmacological effect of THAM on the respiratory centre or the chemoreceptors.

(2) An increase of $\mathrm{pH}$ due to the properties of THAM as a base.

(3) A decrease in $\mathrm{PcO}_{2}$.

Observations made by Ngai et al. (1961) and by Nahas et al. (1963) did not favour the first of these hypotheses, since there was little depression of respiration when a THAM solution buffered to $p \mathrm{H} 7 \cdot 4$ was administered.

The decrease of $\mathrm{H}^{+}$ion concentration and the consequent abolition of an important respiratory 
TABDE

Effect of THAM on Ventilati产,

\begin{tabular}{|c|c|c|c|c|c|c|c|}
\hline \multirow{2}{*}{ Experiment No. } & \multirow{2}{*}{ THAM (mmole/kg.) } & \multicolumn{2}{|c|}{ Resp. Rate/min. } & \multicolumn{2}{|c|}{$\mathrm{V}_{\mathbf{T}}(\mathrm{ml})}$. & \multicolumn{2}{|c|}{$\dot{\mathrm{V}}_{\mathbf{E}}$ (ml./min.) } \\
\hline & & Control & Max. & Control & Max. & Control & Max. 듬 \\
\hline
\end{tabular}

$\mathrm{V}_{\mathrm{T}}$, tidal volume (ml.) BPTS; VE, ventilation (ml./min.) BTPS; $\mathrm{pH}$ (act.), actual arterial $p \mathrm{H} ; \mathrm{pH}(\mathrm{qu} 40) ; p \mathrm{H}$ equilibrated at Pco $40 \mathrm{~mm} . \mathrm{Hg} ;$ diflay

* Blood samples not taken at time of maximum change in $\mathrm{pH}$.

TABËE

Effect of Sodium Bicarbonateicin

\begin{tabular}{|c|c|c|c|c|c|c|c|}
\hline \multirow{2}{*}{$\begin{array}{c}\text { Experi- } \\
\text { ment } \\
\text { No. }\end{array}$} & \multirow{2}{*}{$\underset{(\mathrm{mmole} / \mathrm{kg} .)}{\mathrm{NaHCO}_{3}}$} & \multicolumn{2}{|c|}{ Resp. Rate/min. } & \multicolumn{2}{|c|}{$\mathrm{V} \mathbf{T}(\mathrm{ml})}$. & \multicolumn{2}{|c|}{$\dot{\mathrm{V}}_{\mathbf{E}}(\mathrm{ml} . / \mathrm{min})}$. \\
\hline & & Control & Max. & Control & Max. & Control & Max. \\
\hline $\begin{array}{l}1 \\
2 \\
3 \\
4 \\
5 \\
6 \\
7\end{array}$ & $\begin{array}{l}1 \\
1 \\
1 \\
2 \\
2 \\
1 \\
1\end{array}$ & $\begin{array}{l}44 \\
44 \\
51 \\
58 \\
44 \\
42 \\
44\end{array}$ & $\begin{array}{l}48 \\
41 \\
54 \\
58 \\
51 \\
62 \\
52\end{array}$ & $\begin{array}{l}30 \\
24 \\
36 \\
25 \\
40 \\
27 \\
17\end{array}$ & $\begin{array}{l}52 \\
45 \\
48 \\
44 \\
79 \\
34 \\
40\end{array}$ & $\begin{array}{r}1370 \\
1039 \\
1853 \\
1446 \\
1799 \\
1138 \\
777\end{array}$ & $\begin{array}{l}2512 \\
2302 \\
2590 \\
3667 \\
4077 \\
2119 \\
2083\end{array}$ \\
\hline
\end{tabular}

$\frac{\omega}{\infty}$

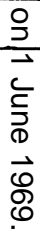
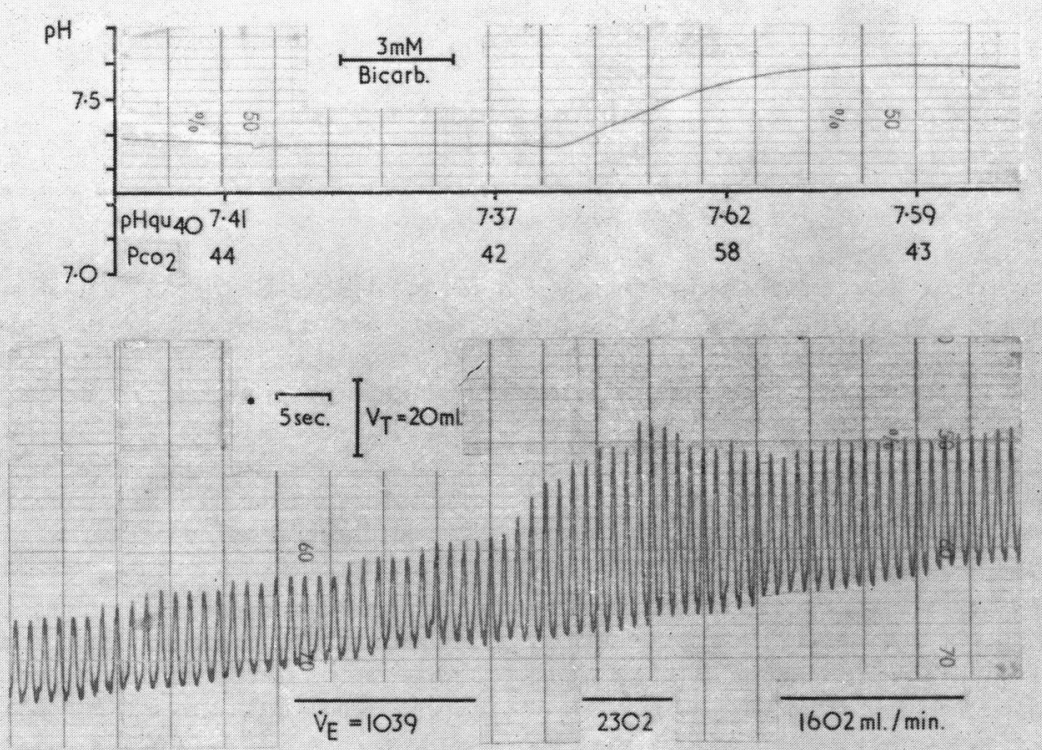

FIG. 3.-Spirogram (lower trace) and arterial $\mathrm{pH}$ (upper trace) before, during, and after injection of 3 mmole sodium bicarbonate. 
Arterial $\mathrm{pH}$, and $\mathrm{PCO}_{2}$

\begin{tabular}{|c|c|c|c|c|c|c|c|c|}
\hline \multicolumn{2}{|c|}{$p H$ (act.) } & \multicolumn{2}{|c|}{$p H(q u 40)$} & \multicolumn{2}{|c|}{$\mathrm{PCO}_{2}(\mathrm{~mm} . \mathrm{Hg})$} & \multirow{2}{*}{$\begin{array}{c}\text { Duration of } \\
\text { Apnoea } \\
\text { (sec.) }\end{array}$} & \multirow{2}{*}{$\begin{array}{c}\text { Duration of } \\
\text { Depr. } \\
\text { (sec.) }\end{array}$} & \multirow{2}{*}{$\begin{array}{l}\text { Dela) } \\
\text { (sec.) }\end{array}$} \\
\hline Control & Max. & Control & Max. & Control & Max. & & & \\
\hline $\begin{array}{l}7 \cdot 43 \\
7 \cdot 39 \\
7 \cdot 50 \\
7 \cdot 35 \\
7 \cdot 35 \\
7 \cdot 35^{\star} \\
7 \cdot 41^{\star}\end{array}$ & $\begin{array}{l}7 \cdot 63 \\
7 \cdot 64 \\
7 \cdot 88 \\
8 \cdot 00 \\
8 \cdot 00 \\
7 \cdot 36^{\star} \\
7 \cdot 55^{\star}\end{array}$ & $\begin{array}{l}7 \cdot 40 \\
7 \cdot 43 \\
7 \cdot 36 \\
7 \cdot 35 \\
7 \cdot 35 \\
7 \cdot 38^{\star} \\
7 \cdot 36^{\star}\end{array}$ & $\begin{array}{l}7 \cdot 59 \\
7 \cdot 68 \\
7 \cdot 52 \\
7 \cdot 56 \\
7 \cdot 62 \\
8 \cdot 40^{\star} \\
7 \cdot 49^{\star}\end{array}$ & $\begin{array}{l}38 \\
38 \\
26 \\
42 \\
42 \\
46^{\star} \\
36^{\star}\end{array}$ & $\begin{array}{l}28 \\
21 \\
12 \\
18 \\
13 \\
47^{\star} \\
33^{\star}\end{array}$ & $\begin{array}{c}\text { Nil } \\
\text { Nil } \\
50 \\
60 \\
5 \\
\text { Nil } \\
5\end{array}$ & $\begin{array}{r}60 \\
65 \\
105 \\
115 \\
30 \\
90 \\
80\end{array}$ & $\begin{array}{r}15 \\
10 \\
35 \\
40 \\
65 \\
12 \\
8\end{array}$ \\
\hline
\end{tabular}

time elapsing until response to drug; max., maximum of alteration of the value.

II

Ventilation, Arterial $\mathrm{pH}$, and $\mathrm{PCO}_{2}$

\begin{tabular}{|c|c|c|c|c|c|c|}
\hline \multicolumn{2}{|c|}{ pH (act.) } & \multicolumn{2}{|c|}{$p H(q u 40)$} & \multicolumn{2}{|c|}{$\mathrm{PCO}_{2}(\mathrm{~mm} . \mathrm{Hg})$} & \multirow{2}{*}{ Delay (sec.) } \\
\hline Control & Max. & Control & Max. & Control & Max. & \\
\hline $\begin{array}{l}7 \cdot 43 \\
7 \cdot 39 \\
7 \cdot 37 \\
7 \cdot 38 \\
7 \cdot 35 \\
7 \cdot 41 \\
7 \cdot 44\end{array}$ & $\begin{array}{l}7 \cdot 42 \\
7 \cdot 58 \\
7 \cdot 51 \\
7 \cdot 60 \\
7 \cdot 60 \\
7 \cdot 65 \\
7 \cdot 64\end{array}$ & $\begin{array}{l}7 \cdot 41 \\
7 \cdot 35 \\
7 \cdot 36 \\
7 \cdot 40 \\
7 \cdot 36 \\
7 \cdot 35 \\
7 \cdot 44\end{array}$ & $\begin{array}{c}7 \cdot 62 \\
7 \cdot 62 \\
7 \cdot 61 \\
7 \cdot 73 \\
- \\
7 \cdot 77 \\
7 \cdot 69\end{array}$ & $\begin{array}{l}39 \\
37 \\
41 \\
45 \\
30 \\
35 \\
42\end{array}$ & $\begin{array}{l}94 \\
58 \\
59 \\
65 \\
58 \\
49\end{array}$ & $\begin{array}{r}15 \\
10 \\
5 \\
25 \\
15 \\
20 \\
15\end{array}$ \\
\hline
\end{tabular}

stimulus seem to be of more importance. It is well known that a decrease in $p \mathrm{H}$ and an increase of $\mathrm{PCO}_{2}$ have additive effects (within physiological range) as respiratory stimulants. There is agreement that $p \mathrm{H}$ increases, after the administration of THAM, but there is no accepted opinion about the effect on $\mathrm{PcO}_{2}$ (Cosby et al., 1964; Henschler, 1963; Nahas and Lumpkin, 1959; Nahas et al., 1963). The results of our experiments are in agreement with those of Nahas et al. (1963); they show a brief but significant decrease of $\mathrm{PCO}_{2}$ followed by a secondary normo- or hypercapnic phase caused by the hypoventilation (Fig. 2). The duration of each of these two phases is between 20 and 30 seconds, so that if only random tests are made, the results will depend on the time of sampling.

In asphyxiated and acidotic newborn infants, hypercapnia is always present. Therefore, the hypocapnic effect of THAM is probably advantageous. Moreover, the effect of THAM does not depend on adequate ventilation, as is the case in bicarbonate buffering. For these reasons the use of THAM seems logical for the rapid correction of the acidosis of this situation.

But an important disadvantage of THAM is the danger of respiratory depression. Nahas and
Holmdahl (1961) pointed out that THAM should be used only when artificial ventilation can be applied. Its use in the newborn infant has been associated with respiratory depression on various occasions (Cosby et al., 1964; Jarre et al., 1965).

The buffering system bicarbonate/carbonic acid has the advantage of a rapid elimination of the acid component by the lung, the $\mathrm{CO}_{2}$ formed by the buffering process being eliminated quickly so long as breathing is adequate. But if pulmonary function is inadequate, $\mathrm{CO}_{2}$ will be retained, and the alkalizing effect of the buffer will be partially offset by the increased $\mathrm{PCO}_{2}$. The gradual ascent of the $p \mathrm{H}$ curve shown in Fig. 3 is caused by an increase in both bicarbonate and $\mathrm{PCO}_{2}$. If the rabbit had not been able to exhale $\mathrm{CO}_{2}$, the increase of $\mathrm{pH}$ would probably have started even more gradually. Holmdahl et al. (1961) obtained similar results.

Transferred to the conditions of the depressed and/or apnoeic newborn, this means that the second phase of the bicarbonate buffering, the elimination of the acid component of the system, is absent. On these grounds, the value of buffering the apnoeic newborn with sodium bicarbonate should be questioned.

A high $\mathrm{PCO}_{2}$ may have two undesirable conse- 
quences. First, a markedly raised $\mathrm{Pco}_{2}$ (above $80 \mathrm{~mm} . \mathrm{Hg}$ ) depresses the respiratory centre (Asmussen and Nielsen, 1957; Graham, Hill, and Nunn, 1960). Secondly, $\mathrm{CO}_{2}$ as an easy diffusible gas may invade the intracellular space more rapidly than the bicarbonate ion (Adler, Roy, and Relman, 1965a, b). It is therefore possible that the intracellular acidosis may be increased, and Adler et al. (1965a, b) found that the intracellular $p \mathrm{H}$ decreased if $\mathrm{PcO}_{2}$ in the extracellular fluid exceeded $70 \mathrm{~mm} . \mathrm{Hg}$. Thus the administration of sodium bicarbonate for the treatment of the asphyxiated newborn seems to be appropriate only if adequate ventilation has been established to ensure elimination of $\mathrm{CO}_{2}$.

The above considerations lead us to suggest a sequential therapy for asphyxia of the newborn.

Initially, i.e. immediately after the delivery of an apnoeic child, THAM should be administered because its alkalizing effect is more reliable than that of bicarbonate.

Saling (1966) has recommended that in all cases where $p$ Hqu 40 values below $7 \cdot 15$ have been found by fetal blood sampling, a maximum dose of 7 mmole THAM should be given to the baby on delivery. $2 \mathrm{ml} .40 \%$ THAM solution ( 3.3 molar) in $10 \mathrm{ml} .10 \%$ glucose is made up, and of this solution up to $4 \mathrm{ml}$. $/ \mathrm{kg}$. body weight is injected via the umbilical vein.

If spontaneous respiration has started or if artificial ventilation has been established, sodium bicarbonate is given. This has the advantage of avoiding respiratory depression, hypoglycaemia, and disturbance of potassium level, which are all possible effects of THAM.

Dosage may either be based on the scheme of Hutchison et al. (1962): volume of $8 \cdot 4 \% \mathrm{NaHCO}_{3}$ required $(\mathrm{ml})=$. base deficit $(\mathrm{mEq} / \mathrm{l}.) \times \mathrm{kg}$. body weight $\times 0.35$, or that of Saling (1966) who suggests a gradual correction of acidosis $(4 \mathrm{ml}$. of $8 \cdot 4 \%$ $\mathrm{NaHCO}_{3}$ per kg. body weight) depending on $p \mathrm{H}$ values.

\section{Summary}

In experiments on rabbits, the influence of buffering substances in acid-base balance and respiration was measured using spirometry and continuous measurement of arterial $p \mathrm{H}$.

A sequential therapy of the acidosis of the asphyxiated newborn is suggested. An initial injection via the umbilical vein of THAM in a maximum dose of $7 \mathrm{mmole}$ is given. As soon as spontaneous or artificial respiration is established, treatment of the acidosis is continued with sodium bicarbonate.
Such sequential therapy aims to correct the acidosis rapidly, without increasing the hypercapnia and intracellular acidosis, while avoiding the sideeffects caused by THAM.

REFERENCES

Adler, S., Roy, A., and Relman, A. S. (1965a). Intracellular acidbase regulation. I. The response of muscle cells to changes in $\mathrm{CO}_{2}$ tension or extra-cellular bicarbonate concentration 7. clin. Invest., 44, 8.

_ - , and $-(1965 \mathrm{~b})$. Intracellular acid-base regulation. II. The interaction between $\mathrm{CO}_{2}$ tension and extracellular bicarbonate in the determination of muscle cell $\mathrm{pH}$. ibid., 44, 21 .

Asmussen, E., and Nielsen, M. (1957). Ventilatory response to $\mathrm{CO}_{2}$ during work at normal and at low oxygen tensions. Acta physiol. scand., 39, 27.

Berg, D., Mülling, M., Marcks, C., and Saling, E. (1968). Beitrag zur Pufferwahl bei der Behandlung der Neugeborenen-Acidose unter besonderer Berücksichtigung der Puffereinflusses auf die Atmung. Arch. Gynäk., 206, 215.

Brown, E. S., Bennett, T. E., Bunnell, I. L., Elam, J. O., Evers, J. L., Greene, D. G., Janney, C. D., Lowe, H. J., Nahas, G. G., and Tarail, R. (1959). Effects of THAM during $\mathrm{CO}_{2}$ breathing in man: ventilation and $\mathrm{CO}_{2}$ exchange. Physiologist, 2 (3), 18.

- -, Greene, D. G., Elam, J. O., Evers, J. L., Bunnell, I. L., and Lowe, H. J. (1961). Effects of 2-amino-2-hydroxymethyl1, 3-propanediol on $\mathrm{CO}_{2}$ elimination and production in normal man. Ann. N.Y. Acad. Sci., 92, 508.

Cosby, R. S., Swan, D. A., Mayo, M., Roberts, D. L., and Richardson, T. R. (1964). Respiratory effects of Tris (THAM) in acidosis and alkalosis. Clin. Pharmacol. Ther., 5, 185.

Graham, G. R., Hill, D. W., and Nunn, J. F. (1960). Die Wirkung hoher $\mathrm{CO}_{2}$-Konzentrationen auf Kreislauf und Atmung. Anaesthesist, 9, 70.

Henschler, D. (1963). Trispuffer (THAM) als Therapeutikum. Dtsch. med. Wschr., 88, 1328. (Eng. trans., Germ. med. Mth., 8, 423.)

Holmdahl, M. H., Nahas, G. G., Hassam, D., and Verosky, M. (1961). Acidbase changes in the cerebrospinal fluid following rapid changes in the bicarbonate/carbonic acid ratio in the blood. Ann. N.Y. Acad. Sci., 92, 520.

Hutchison, J. H., Kerr, M. M., McPhail, M. F. M., Douglas, T. A. Smith, G., Norman, J. N., and Bates, E. H. (1962). Studies in the treatment of the pulmonary syndrome of the newborn. Lancet, 2, 465.

Jarre, W., Ketterle, W., and Reinwein, H. (1965). Zur Behandlung des Respiratory-Distress-Syndrome bei Frühgeborenen mit Tris-(hydroxymethyl)-aminomethan (THAM) und Netzmittel. Helv. paediat. Acta, 20, 27.

Müller-Plathe, O. (1965). Klinisch-pharmakologische Grundlagen der Azidosebehandlung. Münch. med. Wschr., 107, 583.

Nahas, G. G., Fink, B. R., Ploski, W. S., and Teneick, R. E. (1963). The depressant effects of tris-(hydroxymethyl)-aminomethane and of mannitol on respiration. Ann. N.Y. Acad. Sci., 109, 783. , and Holmdahl, M. H. (1961). The clinical use of THAM. F. Amer. med. Ass., 175, 255.

ventilation of the resting dog. Physiologist, 2 (3), 87.

Ngai, S. H., Katz, R. L., Nahas, G. G., and Wang, S. C. (1961). Effects of 2-amino-2-hydroxymethyl-1, 3-propanediol on the central respiratory mechanisms in the cat. Ann. N.Y. Acad. Sci., 92, 632.

O'Connor, T. F., Nahas, G. G., Berman, L. B., and Luchsinger, P. C. (1959). The respiratory effects of THAM in man. Physiologist, 2 (3), 92.

Saling, E. (1966). Das Kind im Bereich der Geburtshilfe. Thieme, Stuttgart.

Siggaard Andersen, O. (1962). The pH-log $\mathrm{pCO}_{2}$ blood acid-base nomogram revised. Scand. F. clin. Lab. Invest., 14, 598.

Correspondence to Dr. E. Saling, Arbeitsgruppe für perinatale Klinik und Forschung, 1 Berlin 44, Mariendorfer Weg 28-38, Germany. 